\title{
Elizabeth Bowen and the New Cosmopolitanism
}

Nels C. Pearson

Fairfield University, npearson@fairfield.edu

Follow this and additional works at: https://digitalcommons.fairfield.edu/english-facultypubs

Copyright 2010 Twentieth Century Literature.

Archived with permission of copyright holder.

\section{Peer Reviewed}

\section{Repository Citation}

Pearson, Nels C., "Elizabeth Bowen and the New Cosmopolitanism" (2010). English Faculty Publications.

18.

https://digitalcommons.fairfield.edu/english-facultypubs/18

\section{Published Citation}

Pearson, Nels. "Elizabeth Bowen and the New Cosmopolitanism," Twentieth Century Literature. 56:3 (2010): 1-26.

This item has been accepted for inclusion in DigitalCommons@Fairfield by an authorized administrator of DigitalCommons@Fairfield. It is brought to you by DigitalCommons@Fairfield with permission from the rightsholder(s) and is protected by copyright and/or related rights. You are free to use this item in any way that is permitted by the copyright and related rights legislation that applies to your use. For other uses, you need to obtain permission from the rights-holder(s) directly, unless additional rights are indicated by a Creative Commons license in the record and/or on the work itself. For more information, please contact digitalcommons@fairfield.edu. 


\title{
Elizabeth Bowen
}

\section{and the New Cosmopolitanism}

\author{
Nels C. Pearson
}

The weight of being herself fell on her like a clock striking. She saw the clothes she would put on to go home in hanging over a chair. While it is still Before, Afterwards has no power, but afterwards it is the kingdom, the power and the glory.... What [my family] can never know will soon never have been... I s shall die like Aunt Violet wondering what else there was; from this there is no escape for me after all. She must rely on marriage to carry her somewhere else. Till it did, she stayed bound to a gone moment, like a stopped clock with hands silently pointing at an hour it can not be.

—Elizabeth Bowen, The House in Paris (133-34)

Looking down, it seemed to Lois they lived in a forest; space of lawns blotted out in the pressure and dusk of trees. She wondered they were not smothered ... Far from here, too, their isolation became apparent ... till the far hills, faint and brittle, straining against the inrush of vaster distance, cut the droop of the sky like a glass blade.

—Elizabeth Bowen, The Last September (92)

$\mathrm{E}_{1}$ lizabeth Bowen's prose offers compelling, often perplexing representations of time and space. Syntax, diction, and metaphor almost heavyhandedly imply that time or space are somehow out of joint, anomalous, disjunct; yet the narrative remains essentially linear or objectively framed, sometimes insistently so. When on the verge of depicting subjective time, 
à la Virginia Woolf, Bowen jostles back to an objective voice; likewise, just as she approaches the "spatial language [of] modernist 'style,",-Frederic Jameson's phrase for how English modernists render "the unrepresentable [social] totality" in figures of vague, vast, ever-expanding space (58-59)something solid "strain[s] against the inrush of vaster distance" (Bowen, Last September 92). Like so much in her fiction, Bowen's treatment of time and space is difficult to interpret, exemplifying what Susan Osborn so accurately describes as the "shot-through queerness" of the author's work - the way its stylistic quirks, "destabilizing ... contradictions and ambiguities" and odd syntaxes evoke ideas that we can fully attribute neither to the characters' experiences nor to the "manifest political conflict" in which they take place (189). As much as I agree and sympathize with Osborn, I think we do stand a chance of comprehending this feature of Bowen's work, especially when we contrast it with representations of time and space that are more typical of early twentieth-century British modernism and that reflect its inclination to negate or suspend the geographic parameters and accumulated history of the imperial nation-state. Studying this contrast in the following pages, I will argue that the crucial difference-Bowen's refusal to propose subjective time and abstract space as the opposites of and successors to a prior modality defined by historical and geographic orientation or rootedness-encourages us to consider Bowen's work in a new theoretical context: the shifting discourse of cosmopolitanism in critical approaches to global democracy.

\section{The cosmos and early British modernism}

Older ideas about cosmopolitanism, including many that remained central to the intellectual climates of early twentieth-century London, are derived from a rational view of statehood and the function of achieved or settled states that developed in the Enlightenment. In 1795 Immanuel Kant disdained "the opposition of states" but deduced that such belligerent opposition was rational, or integral to natural design, insofar as it was a logical precondition for "a law of equilibrium [between] secure ... state[s]" (257) — a precursor for a "distant international government for which there is no precedent in world history" that would promote the "universal cosmopolitan condition, which Nature has as her ultimate purpose" (260). The best evidence for this, Kant proposes, is subjective: the individual's sense that something about the present system is at odds with his or her noblest 
aspirations, a sense he describes as a "rising feeling which each [individual in a state] has for the preservation of the [global] whole" (260). As in the Critique of Judgment, the subject perceives its universality via a feeling that the present milieu (in this case, the "established state" [257]) cannot accommodate. Because no objective structure exists to focus this subjective sensation of universality, it can find expression only in metaphorical or abstract figures of a global community, a world unity with "no precedent" located in the "distant" future.

Interpreting modernist style as a vehicle for such postnational cosmopolitan belonging was central to the production and early critical study of international English-language modernism. Those invested in the idea of an avant-garde "era of artistic migration and internationalism" (Bradbury and McFarlane 13) saw its experimental aesthetic gestures as an analogue for this abstract or subjective "universality." For example, addressing the combined effect of experimental form in Pound, Eliot, and Joyce, Hugh Kenner writes that the "province of these works, as never before in history, is the entire human race speaking, in time as well as in space" (95). Many early contributors to British modernism, defining London as a cosmopolitan rather than a national center, depict the dissociation from national histories and geographies as an encounter with-or a rising feeling of being subsumed within - universal time or space, and also make this sharp contrast central to their aesthetic vision. In his "Vorticist Manifesto," for example, Wyndham Lewis champions the "fundamental Artist that . . has ceased to belong to any milieu or time" (2310), curses the Victorian idea that "London [is] a provincial town," and blesses the "vast planetary abstraction of the ocean" (2316-18). In "Hugh Selwyn Mauberly," his "farewell to London" (382n), Ezra Pound decries a "botched civilization" (385), envisioning in its stead "siftings on siftings in oblivion, / Till change hath broken down / All things save Beauty alone" (389). ${ }^{1}$

British modernist treatments of universality, or non-nationalistic modes of human interconnection, are of course not limited to such abstract and absolute proclamations. As Rebecca Walkowitz has demonstrated, "modernist style" often resists nationally sanctioned modes of imagining community-Woolf's "evasive" subjectivity as an "alternative to wartime patriotism" (18), for example - so as to engage alternative modes of community, as in Joyce's, Conrad's, and Woolf's focus on quotidian, subnational, microcosmic human relationships. Rather than simply promoting an ideal "planetary detachment," such authors assume a more grounded 
cosmopolitan "stance," resisting the consensus-building narratives of realism and nationalism and promoting new "communal aspirations, urban patterns of participant observation, and ethnographic self-consciousness" (10). ${ }^{2}$ Challenging entrenched perceptions of national community to open space for such subversive behaviors, however, many prominent early British modernists, artistically compelled by the English empire, still imagine scenes of sociopolitical disaffiliation that evoke Kant's opposition between "established states" and the "ultimate" cosmos. Certain of their aesthetic maneuvers, that is, work to negate something that can only be bestowed in the first place by the sovereign imperial state: the notion of a normative, stable, or "traditional" correspondence between history and geography. Woolf's, Forster's, and Conrad's representations of space and time, in particular, sometimes implicitly oppose the oriented consciousness of the past to a new, ideologically liberated consciousness of space and time as vast, dark, immaterial, subjective, uncanny, uncontained or ungoverned. As Louis muses in Woolf's The Waves, "the lighted strip of history is past and out; Kings and Queens; we are gone; our civilization; the Nile; and all life. Our separate drops are dissolved; we are extinct, lost in the abysses of time, in the darkness" (225). While such writers don't always execute this absolute negation, at some point, perhaps, they must do so to disengage the inherited weight of established national traditions, state-sanctioned ethics, and imperial cartographies. ${ }^{3}$ When Mrs. Moore visits the Marabar Caves in $A$ Passage to India, for example, her sudden estrangement from British-and more broadly Western-sociocultural interpellation is figured as the subjective inrush of a universal void, an echo that "undermine[s] her hold on life" by "murmur[ing]" that "[e] verything exists, nothing has value" (165), leaving her "terrified over an area larger than usual," lost in a "universe [that] offered no repose to her soul" (166).

This opposition of national and universal belonging emerges again when, after his effort to prove Aziz's innocence makes him feel "devoid of the fervours of nationality or youth" (210), Fielding reflects on the significance of his actions:

he went on to the upper verandah for a moment, where the first object he saw was the Marabar Hills.... It was the last moment of the light, and ... At the moment [the hills] vanished [from sight] they were everywhere, the cool benediction of the night descended, the stars sparkled, and the whole universe was a hill.

(211-12) 
Ian Baucom has argued that "Englishness [since the mid-nineteenth century] has consistently been defined through appeals to the identityendowing properties of place" and that these "synecdoches of the nation's space ... have also been apprehended as temporal contests, [sites in which to dispute and] determine the meaning and the authority of the "English' past" (4). Given the immense weight of this tradition, and in order to introduce in its stead the possibility of postimperial encounters and global-cultural self-consciousness, Forster imagines a total, if momentary, universalizing of all spaces-moments when the places representing Englishness and English historical consciousness are no longer simply up for debate but lost entirely, subsumed by the undifferentiated, synchronic universe. ${ }^{4}$ And as with Forster, so with Woolf. Mrs. Ramsay muses in To the Lighthouse:

this self having shed its attachments was free for the strangest adventures.... Her horizon seemed to her limitless. There were all the places she had not seen; the Indian plains; she felt herself pushing aside the thick leather curtain of a church in Rome.

This core of darkness could go anywhere, for no one saw it. (62)

\section{The postcolonial cosmopolitan difference}

This stylistic predisposition in British modernism's emerging modes of cosmopolitan consciousness speaks to a presumed relationship among lost and gained modes of affiliation, past and present spheres of belonging, national and transnational ways of identifying oneself that are significantly different from at least one key component of cosmopolitanism as it has been considered from postcolonial and minority transnational perspectives. That component is the need to recognize new associations beyond the homeland while also accounting for the unresolved status of one's prior national belonging: the feeling that one has yet to belong to a stable consensus of nationhood, the volatile association with a postcolonial state whose normative form is disputed and still in process, and the immediate need for protective association with sovereign states (as in the procurement of new or dual citizenship). For many postcolonial and minority transnational subjects, new communal identities are not so clearly contingent on rejecting a previously embodied national and cultural episteme- - on what Jessica Berman, in discussing the cosmopolitanism 
of modernist narrative, calls "a wholesale rejection of the politics linked to realism and consensus ... implicated in the imagining of the imperial nation-state" (21).

Especially in postcolonial and transnational forums, the term cosmopolitan therefore vacillates between positive and pejorative connotations, ${ }^{5}$ but it has also, in contrast with earlier uses of the term, helped to identify experiences in which dislocation becomes relocation, mobility beyond cultural borders becomes movement between them, and departure from and attachment to national states (especially when complicated by subaltern occlusion) are not incompatible but vitally connected phenomena. ${ }^{6}$ Further, it identifies forms of travel in which world territory is never a vague, dim, unbordered space but a continually material (if cartographically and historically complex) ground.

In a recent study of cosmopolitanism in postcolonial and transnational contexts, Sheldon Pollock and his coeditors call for a "cosmopolitanism grounded in the tenebrous moment of transition" and champion "emergent discourses of cosmopolitanism [that reflect] our need to ground our sense of mutuality in conditions of mutability, and to learn to live tenaciously in terrains of historic and cultural transition" (4-5). Like other advocates of a postcolonial cosmopolitanism, they propose that, in our thinking about global collectives, we take serious account of intermittent and polyvalent but still concrete affiliations with nations, states, cultures, and localities. This means recognizing that for many, if not the majority, of people on earth, movement beyond the homeland (whether physical, psychological, ideological, or aesthetic) rarely involves absolute gestures of postnational imagination but instead remains subnational and dynamic, for it is typically undertaken while one's nation is still a disputed concept applied to a disputed territory, and while the naturally diverse, vital, and porous culture related to one's national belonging remains contested or ideologically overdetermined. It means being aware, with Pheng Cheah, that it is therefore insufficient to think of a national-cultural framework as a previously existing or formerly accepted situation out of which one critically emerges. Instead, it is a "nontranscendable moving ground extending across the globe" "“Given Culture" 324).

In various modes of postcolonial travel, to experience one's serially interrupted national and cultural processes as "nontranscendable" is not to remain bound within the ideological context of a particular place (as in fundamentalist forms of nationalism) but to construct new affiliations 
while also being concerned for the material needs and hopes tied to the incomplete nationhood of "home." " Understanding deferred and mobile attachment in the context of one's homeland enables one to understand it elsewhere, and thus to see the world as populated by settlers and travelers involved in distinct, sometimes multiple, regional economies, cultures, and political processes. Perhaps most importantly, this understanding allows one to see civilization as still in the process of being made rather than as a "botched" project - to visualize a world populated largely by those still waiting for and working for the convergence of national belonging, equitable statehood, and international exchange. In the governing metaphor of cosmopolitics, it allows one to be a grounded traveler, someone "connected to the earth-but not to 'a' place on it [whose essence we can presume to be as] simple and self-evident as the surroundings we see when we open our eyes" (Robbins 3).

\section{Elizabeth Bowen: tenacious cosmopolitan}

Bowen's life was quintessentially cosmopolitan in what we might call the older, mid-twentieth-century understanding of the term. She moved between, and used as settings, many of the major cities in the network of international modernism, such as London, Paris, Rome, and New York. Indeed, few things are more characteristic of Bowen than mobile characters, transient lives, and the exaggerated distances and proximities of wartime played out at the level of the personal. But unlike many modernists, she does not treat this restlessness as part of a historically new, ontologically revelatory mode of thought and experience. In Bowen, attachments to place are as contingent as separations, typically partial and always in process. Especially for her female protagonists, displacement is the norm of the present, but it has also been the norm of the past. In The Death of the Heart, for example, Portia Quayne ends up as "a refugee" who "seemed to belong nowhere, not even [this] temporary little stale [hotel] room" (293), but there is nothing new in this displaced condition, for she "had grown up exiled not only from her own country but also from normal, cheerful family life" (15; Bowen's italics) before coming to stay with her London relations. Rather than citizens of the world who have undergone an initiatory exile or uprooting, Bowen heroines are usually in process of negotiating belonging relative to one or more adoptive families, past affiliations, or foreign communities, and they are just as likely to cherish 
separation from these as to seek attachments. As Bowen writes regarding Portia, "It is not our exalted feelings, it is our sentiments that build the necessary home. The need to attach themselves makes wandering people strike roots in a day: whenever we unconsciously feel, we live" (140).

Indeed, as much as they "enjoy the sensation of being on furlough from [their] own li[ves]" (Heat 103) or desire "to be enclosed in a nonentity, in some ideal no-place, perfect and clear as a bubble" (Last September 127), they also yearn "to be in a pattern ... to be related" (142). Like Karen Michaelis in The House in Paris, they are inclined to "hate exile, hate being nowhere, hate being unexplained, hate having no place of [their] own" (207). Notions of transnational modernity involving an unprecedented estrangement thus don't illuminate their predicaments. It is not that they once belonged somewhere else and suddenly feel adrift in the globe-as-universe; rather, they always "belong somewhere else" (Heat 115). As Bowen writes of her Anglo Irish heroine Stella Rodney in The Heat of the Day, "The times, she had been told in her youth on all sides, were without precedent - but then, so was her own experience: she had not lived before" (24). This sentence encapsulates the most pervasive characteristic of Bowen's focal characters: they do not possess an orientation that precedes their disorientation. They live in the present of disruptions and historical crises, but they have not "lived before" in the sense of having experienced a mode of belonging that was, at some point in the past, stable enough to be "botched" by the sudden and seismic turmoil of modernity. Where they come from is still subject to debate "on all sides," still being processed even as they depart or seek new attachments, as is the case for the transient lovers in The House in Paris, To the North, and The Heat of the Day. Their pasts therefore remain material and volatile, liable to intrude upon the present in concrete ways, not just as facets of consciousness or fragments of memory. In The Heat of the Day and The House in Paris, where characters travel from the modernity of London and Paris to the "disturbing repose" of Protestant Ireland during the years when De Valera's Fianna Fail majority was constructing the nationalistic Republic (Heat 75), we get a hint of this process. In The Heat of the Day, Stella must return from "timeless" London to settle the "historic future" (52) of a family estate in Cork - a property that, in its disputed ownership, represents both the ideologically contested enclaves of the Anglo Irish Ascendancy in the nascent Republic and the extensive history of partition and colonization in Ireland more generally. Without prior historical 
and geographic rootedness, Stella's experience of modernity is less about resisting tradition than about the ongoing partiality of her spatial and temporal belonging. ${ }^{8}$

Living in a rented London flat during the blitz, Stella relishes the "hypnotic, futureless day-to-day" of her love affair with Robert Kelway, in which "life stories were shed as so much superfluous weight," and enjoys the feeling that wartime London is absorbed by "the 'time being' which war had made the very being of time" (103). But she also feels "the anxieties of the hybrid" (125) deriving from the difference between shedding a settled history and shedding the disputed history (and property) of the Anglo Irish. That legacy, also Bowen's own, was of a perpetually unsettled, shifting relationship among the nation, the state, and the community and culture of home. As has been well documented, Bowen was deeply aware of the Anglo Irish sense of being stranded between anti-imperial nationalisms increasingly driven by lower-middle-class, rural, Catholic Irish and a British nation whose drift toward capitalist-democratic modernity the Ascendancy had historically defined itself by opposing. ${ }^{9}$ Indeed, the Anglo Irish sense of location, prior to any identifiable modern "moment," was already marked by geographic exclusion and historical dispute, as was Ireland's more broadly.

Not surprisingly, Bowen's sense of time and space as disjunct or anomalous, but not globally expansive or fluidly subjective, is deeply evident in her comments on the Ascendency, whom she describes as "queered - by their ... divorce from the countryside in whose heart their struggle was carried on" (Collected Impressions 197) and as "notably unhistoric" due to having been "left to operate in what was materially a void" (Bowen's Court 452-55). Stella Rodney, an expatriate from a disputed enclave within a disputed state, thus experiences modernity quite differently from those with whom she associates in modern London. One difference is that Stella's experience of modernity does not occur in the aftermath of rootedness: "She, like [Robert], had come loose from her moorings; but while what she had left behind her had dissolved behind her, what he had left behind him was not to be denied" (Heat 125). Consequently, her need for attachment and her capacity for critical detachment are not sequential opposites but almost simultaneous phenomena. Trying to compare her own previous sense of belonging to the "self-evident position" of the family life Robert had left behind in culturally idealized rural England, Stella recalls a "derelict" memorial to Ascendancy gentry in culturally and 
politically contested rural Ireland; this "gave some sort of locale, however distant, to her unmarried name," though "she seldom asked herself what her own was now-still less, what position was in itself" (126). The implied questions here are pivotal: how can one leave behind a world whose location has been unstable from the beginning? If home had always been a contested space, how can one gauge one's detachment from it or evaluate one's new "position" in the present? Although Bowen's world is trans-European and cosmopolitan in an older sense of the term, the combination of present mobility and previous instability, so central to the lives of her characters, strikes much nearer to the ideas of place and time advanced by postcolonial and non-first-world émigrés-of those who emerged not out of a history but with it.

To be sure, Bowen's class status and race, which are often reflected in her characters, distinguish her from what James Clifford calls the "discrepant cosmopolitan" (108) experiences of forced migration and mobile subaltern existence that scholars of transnational culture, following Clifford, have posed against the privileged cosmopolitanism of a predominantly pan-European elite. But like those experiences, hers involve an awareness that even as one is living beyond the homeland, that original place isn't understandable in terms of fixed space or linear time because it involves incongruent and deferred associations among political sovereignty, shared territory, and historical or cultural identity. Even as one becomes separated from such a homeland, then, one cannot simply transcend or emerge from it. In The Last September, Hugo Montmorency, who has returned to the Naylors' Big House in Cork after a ten-year absence, poignantly sums up this contingent sense of position. Asked what he feels will be "the outcome" of the Anglo Irish war, Hugo predicts "a few more hundred deaths on our side - which is no side - rather scared, rather isolated, not expressing anything except tenacity to something that isn't there-that never was there" (117).

As much as The Last September is Bowen's remembrance of things irretrievably past, it also demonstrates what she called "the imperious hauntedness of a period not understood in its own time" (qtd. in DiBattista 233) - the residual urgency of a society that, contemplating its finality, could not agree on its beginning, its normative place in time. ${ }^{10}$ This sense emerges powerfully in the final meeting between Lois and Gerald, appropriately set at the edge of the wooded boundary of the demesne: 
"Where shall we go?" [Lois] asked, while something in her stopped like a clock with foreboding.... She wished they had not come down-overruling, possibly, in each other some desire for space - to the plantation where constricted by firs, thought and movement were difficult and upright shadows emphasized his severity. . . . she saw him standing confused, like a foreigner with whom by some failure in her vocabulary all communication was interrupted. (Last September 279)

For Lois, the thought of making a decisive emotional move is accompanied by the fear that such gestures "finish off people" (252) or "stop, seal, finish one" (83). The consequent indecision also reflects the Irish, and more broadly postcolonial, problem of how to leave behind or "finish" what has lacked integration from the beginning: "'One can't move, one doesn't know where one is.' .. 'But, Gerald, where are we?' He said: 'Don't worry.'They were both, he knew, entirely lost." (282). ${ }^{11}$

Again, however, Bowen largely resists the early British modernist tendency to depict disengagement from the national and imperial milieu with images of synchronic vastness or of the inhabited globe as abstract cosmos. Although her characters experience "cancelled time" (Last September 28), "time lag" (Collected Impressions 4), the "glare of space" and the "unestablishable distance" (Heat 154) or a "slipping and widening [of the] distance" (Last September 86) between one another, they are ultimately subject to the manifest pressures of history and place. Because they haven't experienced a coherent past, they have little investment in what is called "external time." Linear time and historical frameworks are still being constructed: "There had been no beginning. Time, loose textured, had a shining undertone" (Last September 14); "perpetually one was subject to the sense of there having had to be a beginning somewhere. Like the lost first sheet of a letter or missing first pages of a book, the beginning kept on suggesting what must have been its nature" (Heat 146). ${ }^{12}$ Because there is no normative, prior place of belonging, the material environment may verge on dissolving into a universal void or an expanding darkness-departing guests tear "great shreds from the season's texture," Lois's flirtations with a British soldier make "the cracks of the walls ... bulge out visibly" (243), and her run-in with an IRA soldier in a ruined mill makes the cracks in its walls "seem to widen, to ... peel back from a cleft" (180)—but all that is solid never completely melts into air. Although 
figuratively fissured, physical structures like the abandoned mills ("never quite stripped and whitened to a skeleton's decency: like corpses at their most horrible" [178]) and the Naylor home (its door "open hospitably" as the flames consume it [303]), retain their enigmatic physical presence, manifesting how, for Bowen, ideologically contested space disrupts time itself. $^{13}$

Indeed, Lois and Marda's encounter with the gunman is rendered as both elegy and historical nightmare: initially a symbol of "the democracy of ghostliness" (179), the mill ends up housing a microcosm of actors in decolonization's violent present and "affecting [them] like a sense of the future" (182). Thus, where in the Marabar Caves scene in A Passage to India an already settled milieu is swiftly leveled, in the mill scene an unsettled, incompletely internalized milieu rapidly alternates between material and ghostly presence, between assimilation into the generality of history and the irreducible resilience of traumatic memory. The stubborn, enigmatic materiality of unassimilated places, a theme that suffuses Bowen's descriptions of houses and furnishings, is nowhere more evident than in her treatment of Ascendancy property. Compare an exemplary description of a Big House by Bowen to an exemplary depiction by Virginia Woolf of the contest between physical structures and universal time and space. In To the Lighthouse the effect of the Great War is represented by "a downpouring of immense darkness" that engulfs the Ramsay home:

Nothing, it seemed, could survive the flood, the profusion of darkness ... there was scarcely anything left of body or mind by which one could say, "This is he" or "This is she." (125-26)... [Nights] lengthen, they darken. Some of them hold aloft clear planets, plates of brightness. The autumn trees, ravaged as they are, take on the flash of cool cathedral caves where gold letters on marble pages describe death in battle and how bones bleach and burn far away in Indian sands.

In Bowen, by contrast, the Big House is enveloped by a similar profusion of darkness but never fully absorbed:

Only the massed trees ... of the demesne were dark and exhaled darkness. Down among them, dusk would stream up the paths ahead, lie stagnant on lawns, ... dulling the borders as by a rain of ashes. Dusk would lie where one looked as though it were in one's eyes, as though the fountain of darkness were in one's 
own perception. Seen from above, the house in its pit seemed a very reservoir of obscurity ... But as they drove down the home-sense quickened; the pony, knowing these hedges, rocketed hopefully in the shafts. The house became a magnet to their dependence. (Last September 92-93)

For Bowen, the Big House survives the mists of synchronic time, reasserting itself as the half-realized entity it already was: a "reservoir of obscurity." 14 Like Hugo Montmorency's observing the Anglo Irish "expressing ... tenacity to something that . . never was there," the description registers the crucial difference between separation from a home in the throes of decolonization and estrangement from one's place in the achieved nation-state. The latter severs or suspends ties to a structure that had previously fixed both self and world in a coherent frame of reference. The former extends or expands a belonging in progress; that is to say, it takes the local feeling of "being divided in one's self" (Last September 30) and molds it into the globally broader awareness that, as Edward Said has it, "in a secular and contingent world, homes are always provisional" ("Reflections" 185).

\section{Cosmopolitical Bowen}

Like many of the new (and newly identified) cosmopolitans studied in geographically and culturally particularized literature on the subject, Bowen's understanding of departure or expatriation leads not to "an ideal of detachment," as Bruce Robbins puts it, but to "a reality of (re) attachment, multiple attachment, or attachment at a distance" (3). As in her fiction, in her real life and in her more direct political and cultural commentaries, multiple attachments and international dialogue are always bound up with her unsettled but dearly maintained and irreducible Irishness. One cannot delineate an "Irish" from a "post-Irish" period in her literary subjects, her political and historical outlook, or her residency (until, arguably, 1960, when she hastily sold Bowen's Court). ${ }^{15}$ Rather than becoming subsumed into a larger worldview, her Irish outlook remains specifically and elementally present: this is because, as she wrote while reviewing a book on modern Irish history, "nothing in Ireland is ever over" (Collected Impressions 173). Thus, in the political commentaries, book reviews, and literary essays she produced from the late 1920s to the late 1950 s, Bowen's view of the world at large is always in dialogue with her 
view of Ireland's potential futures and its still unreconciled past. Exploring such subjects as Sinn Fein, Irish neutrality, literature and patriotism, and the need to diffuse stereotyping in English/Irish relations, she suggests the vital relationship between the volatility of the nascent postcolonial state, the constructedness of history, and the incipient promise of both Irish and international democracy.

In her 1928 introduction to The Last September, writing at a pivotal moment for the international reputation of the newly formed Irish Free State, Bowen assures her international audience that the troubles are "already part of history" (Mulberry 124), and that with the evanescence of the Big Houses, Ireland is also now geographically unified:

writing The Last September [in 1928 in England], 1920 seemed a long time ago. By now ... peace had settled on Ireland; trees were already branching inside the shells of large burned-out houses; lawns, once flitted over by pleasures, usefully merged into grazing land.

Writing to an Irish audience in a 1940 essay for the Irish literary magazine The Bell, she again tries to promote both democratic Irish statehood and international understanding, though here, seeking to disarm a nowentrenched nationalism, she proposes that Ireland would benefit from resurrecting "the idea from which these houses sprang"- the value of democratic social intercourse both within and beyond the nation-and making it "an alive part in the alive Ireland of today" (Mulberry 29). In a 1941 essay in the British periodical The New Statesman, Bowen again revisits the unsettled history of the Ascendancy, advocating democratic dialogue both within Ireland and between Ireland and Europe: defending the neutral Irish state by deflating rumors of its Axis sympathies and entreating the English to see the new Irish state as "a people young in political life, not yet adult in citizenship, ... and in no sense fit or ready to enter war" (Mulberry 31), she also proposes that Ireland wishes to avoid the "abnormal isolation" of excessive nationalism and the "sequestration from Europe [which] is . . the principal ill of her neutrality" (32-33). ${ }^{16}$ Key to her negotiation is a historical reimagining of the Big House ${ }^{17}$ not as a foreign enclave spatially disrupting the settled state but as a place that potentially embodied ideals of cosmopolitan exchange always already disrupted by their ties to colonialism. As if to graft this version of the Ascendancy to Ireland's vital historical body, Bowen aligns the present- 
day country with such intercultural exchange: "accustomed ... to being much visited . . . by people of cultural sympathies and enquiring mind, the country does not like segregation" and has always been aware that "claustrophobia is the threat to every civilized mind" (32). Bowen is thus looking back to eighteenth-century cosmopolitan ideals, but she is also, in a much more contemporary, cosmopolitical sense, arguing that whereas imperialism forecloses and disavows the cultural plurality it introduces, the postcolonial state- if it agrees to promote "citizenship" and "society" by breaking down "barrier[s] between city and country Ireland" (29) rather than enforcing a singular Irish identity—can reintroduce this lost potential.

Bowen's reflections on James Joyce following his death in 1941 similarly complicate the historical and geographic absolutes that-especially during the Second World War and the nascence of the Republic of Ireland - tended to characterize debates about nationality and allegiance. In a 1942 review of Herbert Gorman's biography of Joyce in England's New Statesman, she notes that in "days when there is a bad name for detachment, it is hard to assess the detached man" and denies that Joyce was simply "an aesthete piqued with his own country, choosing to live abroad" (Mulberry 154); instead, she argues, what made his writing possible was a difficult, painful, and partial separation. She sees Dublin and Catholicism, for Joyce, as milieus "from which a deep nature does not without crisis secede, and from which a lonely nature dreads to detach itself" (155). More extensive in its portrayal of the half-removed Joyce is the reflection she wrote in 1941 for Ireland's cosmopolitan-themed periodical The Bell. ${ }^{18}$ One of the first, if not the first, posthumous defenses of Joyce directed to an Irish audience by an Irish writer, her reflection on why "the death of James Joyce was felt by few in his own land as a personal tragedy" seeks to deconstruct the oppositions of cultural tradition and aesthetic experiment, patriotism and cosmopolitanism, Irishness and exile, that had dominated mainstream assessments of Joyce. "It is surroundings that tie us closely to people, that are the earth of friendship," she concedes,

And that physical, associative tie with his countrymen Joyce broke when he went to live abroad. Yet he was before all an Irishman. All the cerebral complexity of his later art went to reproduce the physical impressions that he had received in Ireland. ("James Joyce" 40) 
She sees Stephen Dedalus as both universal and locally grounded:

Across the quadrangles of old English universities, through the streets of London, New York, Paris have walked many selfseen Stephens.... But to be truly Stephen one must be a born Catholic and Irish city-bred man. "Crying aloud in the rain on the top of the Howth tram"- Stephen is undetachable from his place.

Bowen argues that even Finnegans Wake exhibits a "fundamental Irishness" that "has defeated, and ... antagonized, the critics." But where she is most ahead of her time is in her recognition that to make such a declaration is also to raise the question of what Irishness is in the first place: "The English can never know us - and are we ready to know ourselves? To challenge our view of ourselves ... is more academic than we realize" (41).

Bowen's complex experience of attachment to and detachment from her homeland illuminates her view of the human predicament more broadly - a view of humanity as everywhere bound up with particular, dynamic affiliations. She essentially made this argument in a 1950 article for The New York Times Book Review. Writing to an American audience that, like her English and Irish audiences, was in the throes of what she saw as an excessive but understandable phase of patriotism ("Never has loyalty, on the face of it, been ranked higher than it is today" [Mulberry 60]), she criticizes "restrictive loyalties" (61), but she does so while also addressing the importance of the local: "human values are [the writer's] concern," she argues, but "they are neither abstractions nor standing points ... in their nature not fixed but shifting," subject to "the endlessness of human variation and dissonance, the doublings and twisting of mankind under the grip of circumstance" (60). The writer's "ideal," she concludes, "is to be at once disabused [of] and susceptible to [loyalties], and for ever mobile" (61).

During and after World War II, when her reputation as an English novelist was on the rise, and later, when she was moving between countries, cities, and audiences, Bowen was also returning to her Irish past: to the "anxious history" (452) of her family estate in Cork, in Bowen's Court (1942); to her childhood in Dublin, in Seven Winters (1942); and again to the Big House, in the midst of the Anglo Irish war, in A World of Love (1955), a novel centered on the disruptive return of the unprocessed past. Perhaps the intensity with which she superimposes the need for and the 
inconclusiveness of belonging was, as Victoria Glendenning has observed, most poignantly evident at the end of A Time in Rome, completed in 1960. Writes Glendenning:

The last two sentences of the book, after describing the pain of departure, come as a slight shock. What she wrote, and what she had the panache to leave written, is the controlled, undirected cry of the displaced person: "My darling, my darling, my darling. Here we have no abiding city."

Indeed, throughout Bowen's work, homes and histories of any kind remain as dearly needed as they are forbidding-contingent, volatile, but psychically vital.

\section{Notes}

1. Especially in the case of Pound's "botched civilization," these excerpts exemplify what Walter Mignolo— seeing modernism as "a manifold geohistorical category which was interpreted chronologically within the reduced space of the heart of Europe"-indicts as its "temporal conceptualization of world history" at the expense of a "spatial conceptualization of world histories and relations" (189; Mignolo's italics).

2. Similarly, for Jessica Berman, British modernist fiction often "enacts notions of community that ... undermine political versions of established consensus [and] blind universality [by] decenter[ing] belonging and challeng[ing] commonplace notions of the universal political subject" (22). It thus opens "the possibility of a new cosmopolitanism, one that relies on the contingency of borders to open the community to a wider network of differences" and "widens [the gap] between the theory of community and that of nationality, between a politics of connection and that of the modern nation-state" (15).

3. Jed Esty points out that the "apocalyptic temporalities" (50) and expansive spatial abstractions of British modernism are more typical of early twentiethcentury trends, just prior to the inward, "anthropological turn" (3) in British modernism of the 1930s to 1960s, when the focus turned to the loss of empire and the concern for English nationhood as a phenomenon separate from empire. My analysis here is concerned with a particular aesthetic deployment of space and time that could be considered a component of the early twentiethcentury phase of British modernism that Esty describes. I would add, though, that these expansive, subjective representations of space and time indicate more than just the negative form or imagined loss of the expansive imperial world- 
view of the early century: they also reflect a presumptive linking of nationstate belonging with historically and geographically embedded life and a more general, Eurocentric conceptual opposition between achieved statehood and cosmopolitan life or thought.

4. For Jameson, the figure of "infinity" or an "ever-expanding grey placelessness" in British modernism is the result of an inability to imagine societal cohesion in the metropolitan heart of an expansive empire (57-60). For Edward Said, the modernist "reformulation of . . fragments drawn self-consciously from disparate locations, sources, cultures" indicates a "spatiality" that has become, "ironically, the characteristic of an aesthetic rather than a political domination" (Culture 189-90). My formulation of the problem, though indebted to these observations, also suggests that spatial abstraction or conflation is inseparable from subjective or synchronic temporality, and that this interdependence reflects the inclination of imperial state subjects to imagine local geographic and historical loss in universal terms, or as global in scope.

5. David Chandler and Timothy Brennan argue that cosmopolitanism has not changed much, at least with regard to its underestimation of the sovereign nation-state as the only proven guarantor of rights (Chandler 34-35; Brennan 42). For Brennan, it now merely means "the global entrance into a common hybrid self-consciousness by formerly subjugated peoples, without in the least disturbing the self-portraiture of the West" (45). Meanwhile, commentators such as Kwame Anthony Appiah propose that the term cosmopolitanism "can be rescued" to promote ethical cooperation in the contemporary global arena, given its core principles "that we have obligations to others [which] stretch beyond those to whom we are related by the ties of kith and kind, or even ... shared citizenship" and "that we take seriously the value not just of human life but of particular human lives, which means taking an interest in the practices and beliefs which lend them significance" (xiv-xv). Whereas Brennan sees the concept as neglectful of specific non-Western nation-states in process, for Appiah the new cosmopolitanism recreates, on a global scale, an ideal national model of a dialogue respecting difference, for "it begins with the simple idea that in the human community, as in national communities, we need to develop habits of coexistence: conversation in its older meaning, of living together, association" (xix). Pheng Cheah clarifies that cosmopolitanism at its proper historical epitome (Immanuel Kant's promotion of the concept in 1795) had as its opposite "not nationalism but statism" ("Introduction" 22) and that, then as now, one's obligations to humanity at large and one's "affective and concrete" link to national processes (24), especially those "prior to [their] annexation of the territorial state" (25), are not opposites. Indeed, one constant in these discussions is the need to understand how our engagements with particular 
national or cultural life and our responsibilities to common or global humanity can be collaborative without either form of belonging becoming reductive or insular.

6. As Gita Rajan and Shailja Sharma put it,

new cosmopolitans [are] people who blur the edges of home and abroad by continuously moving physically, culturally, and socially, and by selectively using globalized forms of travel, communication, languages, and technology to position themselves in motion between at least two homes, sometimes even through dual forms of citizenship. (3)

7. Cheah clarifies, for example, that "cosmopolitanisms premised on the transcendence of the given" cultural and socioeconomic collective cannot account "for the majority who remain in peripheral space by choice or necessity"those for whom "the nation-state, whatever its inconveniences, is a necessity," for whom the sovereign and equitable nation-state remains deferred, and for whom "postnationalism through migration is not an alternative" ("Given Culture" 314).

8. As true as it is that, as Maude Ellman argues, "the sense of homelessness so prevalent in Bowen's fiction derives at least in part from the predicament of the Anglo Irish, an alien enclave marooned in its own home" (10), so too is the observation that Bowen's version of homelessness is not the result of a lost home but of homes still sought.

9. For more on the historical and geographic insularity of the Ascendancy in general, see Foster chapter 8. As Billy Gray puts it, "within a comparatively short historical period, the members of Protestant aristocracy who had been the original progenitors of Irish nationalism came to view themselves as exiles within their own country" (85).

10. DiBattista sees in this urgency a source of Bowen's "modernist idiom" (238), recording the disillusionment deriving from the unsettling experience of modernity (238-40). But for Bowen, there is no originally "settled" or "unified" past against which to posit absolutes of disruption.

11. As Beth Wightman observes, “The hole at the center of Lois's identity ... is a fundamental function of place and space" in decolonizing Ireland: "Just as Anglo-Irish culture ... struggles to connect with the land and people surrounding it, Lois cannot connect with a modern Irish nation-state, and she cannot conceive of an intact Irish space on any terms" (55).

12. As Robert Caserio has observed, Bowen's narratives make us "feel the full impact of elemental contingency .... and at the same time the solidarity among 
contingent and heterogeneous elements" (277). "Historical and cultural context," he argues, may thus appear vague or distant, but they ultimately "limit [her characters'] freedom to be arbitrary and groundless." Bowen thus coaxes, but repeatedly rejects, "the full-throated modernist's positioning power, which sunders and dislocates itself from contexts to live out an allegory of freedom."

13. As Neil Corcoran observes, the history of Anglo Ireland and of the colonized, partitioned island more broadly is "still architecturally articulate on the land" (52), embodied in such structures as the deteriorating mill and the silent, perplexed ruins of the Big Houses.

14. The forces threatening to engulf the Naylors' Big House are themselves also difficult to universalize, given their intensely local significance: in County Cork, 1920, the "dusk ... dulling the borders" is the "Irish Ireland" philosophy of Sinn Fein, an impending effort to link national history and state territory predicated on the belief that the "Gael must ... absorb" the vitiating Protestant presence (Moran 43).

15. As is well demonstrated by Maude Ellman and especially Neil Corcoran, Bowen's life and work draw much of their intensity from her physical, topical, and conceptual revisiting of Ireland.

16. Many Anglo Irish intellectuals, in literary circles most notably W. B. Yeats and George Russell, also wished to avoid isolation. Bowen, however, does not idealize particulars of the land and tenant economies, and seems principally (though not stridently) concerned to define Ireland's thwarted, unrealized transnational past as a statewide concern.

17. Julia McElhattan Williams argues that The Last September itself enacts this renegotiation of Anglo Irish presence in Irish history:

by placing fictional characters within a reconstructed past, Bowen offers one possible interpretation of the differences that have separated the Irish from the Anglo-Irish, not merely as [due to] self-interest, but [to] conditions which stemmed from the mismanagement of Ireland under English colonial rule and victimized both the Irish and AngloIrish people. (227)

18. My thanks to Allan Hepburn of McGill University for bringing this article to my attention. Sean O'Faolin, in his inaugural editor's address for the magazine, described its agenda thus: "Whoever you are, Gentile or Jew, Protestant or Catholic, priest or layman, Big House or Small House-the Bell is yours” (qtd. in Keogh). 
I would like to thank Kate Costello-Sullivan of LeMoyne College, who read an early draft of this essay and offered valuable suggestions for its improvement, as well as Emily Orlando of Fairfield University, who gave me savvy editorial advice and much-needed encouragement at multiple stages of the project.

\section{Works cited}

Appiah, Kwame Anthony. Cosmopolitanism: Ethics in a World of Strangers. New York: Norton, 2007.

Archibugi, Daniele, ed. Debating Cosmopolitics. London:Verso, 2003.

Baucom, Ian. Out of Place: Englishness, Empire, and the Locations of Identity. Princeton: Princeton UP, 1999.

Berman, Jessica. Modernist Fiction, Cosmopolitanism, and the Politics of Community. Cambridge: Cambridge UP, 2001.

Bowen, Elizabeth. Bowen's Court. New York: Ecco, 1979.

- Collected Impressions. New York: Knopf, 1950.

- The Death of the Heart. London: Penguin, 1966.

- The Heat of the Day. New York: Knopf, 1949.

- The House in Paris. New York: Random, 2002.

_. "James Joyce." The Bell 1.6 (1941): 40-49.

- The Last September. New York: Random, 2000.

- The Mulberry Tree:Writings of Elizabeth Bowen. London:Virago, 1986.

Bradbury, Malcolm, and James McFarlane. "Preface to the 1991 Reprint." Modernism: A Guide to European Literature 1890-1930. Ed. Malcolm Bradbury and James McFarlane. London: Penguin, 1991. 11-16.

Brennan, Timothy. “Cosmopolitanism and Internationalism.” Archibugi 40-50.

Caserio, Robert L. "The Heat of the Day: Modernism and Narrative in Paul de Man and Elizabeth Bowen.” Modern Language Quarterly 54:2 (1993): 263-84.

Chandler, David. “International Justice.” Archibugi 27-39.

Cheah, Pheng. "Given Culture: Rethinking Cosmopolitical Freedom in Transnationalism." Cheah and Robbins 290-328.

—. "Introduction Part 2: The Cosmopolitical-Today." Cheah and Robbins 20-41.

Cheah, Pheng, and Bruce Robbins, eds. Cosmopolitics: Thinking and Feeling Beyond the Nation. Minneapolis: U of Minnesota P, 1998. Cultural Politics 14.

Clifford, James. "Travelling Cultures.” Cultural Studies. Ed. Lawrence Grossberg et al. New York: Routledge, 1992. 96-116.

Corcoran, Neil. Elizabeth Bowen: The Enforced Return. Oxford: Oxford UP, 2004. 
Elizabeth Bowen and the New Cosmopolitanism

DiBattista, Maria. "Elizabeth Bowen's Troubled Modernism." Modernism and Colonialism: British and Irish Literature, 1899-1939. Ed. Richard Begam and Michael Valdez Moses. Durham: Duke UP, 2007. 226-45.

Ellman, Maude. Elizabeth Bowen:The Shadow across the Page. Edinburgh: Edinburgh UP, 2004.

Esty, Jed. A Shrinking Island: Modernism and National Culture in England. Princeton: Princeton UP, 2004.

Forster, E. M. A Passage to India. New York: Harcourt, 1984.

Foster, R. F. Modern Ireland 1600-1972. New York: Penguin, 1989.

Glendenning,Victoria. Elizabeth Bowen. New York: Avon, 1977.

Gray, Billy. “"The Lukewarm Conviction of Temporary Lodgers': Hubert

Butler and the Anglo-Irish Sense of Exile." New Hibernia Review 9.2 (2005): 84-89.

Jameson, Frederic. "Modernism and Imperialism." Nationalism, Colonialism, and Literature. By Terry Eagleton, Frederic Jameson, and Edward Said. Minneapolis: U of Minnesota P, 1990. 43-67.

Kant, Immanuel. "Idea for a Universal History from a Cosmopolitan Point of View.”Trans. Lewis White Beck. Immanuel Kant: Philosophical Writings.

Ed. Ernst Behler.Vol. 13. New York: Continuum, 1986. 249-62.

Kenner, Hugh. The Pound Era. Berkeley: U of California P, 1971.

Keogh, Dáire. "A World of Ideas Saved by the 'Bell' and the Jesuits." Irish Times 22 Nov. 2008. Web. 2 Feb. 2009.

Lewis, Wyndham. "Vorticist Manifesto." The Longman Anthology of British Literature, 2nd ed.Vol. 2C. Ed. Kevin Dettmar and Jennifer Wicke. Gen. ed. David Damrosch. New York: Longman, 2003. 2310-24.

Mignolo, Walter. "Human Understanding and (Latin) American Interests-The Politics and Sensibilities of Geohistorical Locations." A Companion to Postcolonial Studies. Ed. Henry Schwartz and Sangeeta Ray. Malden: Blackwell, 2000. 180-202.

Moran, D. P. The Philosophy of Irish Ireland. Dublin: James Duffy, 1905.

Osborn, Susan. "Reconsidering Elizabeth Bowen." Rev. of Elizabeth Bowen: The Enforced Return, by Neil Corcoran, and Elizabeth Bowen: The Shadow across the Page, by Maude Ellman. Modern Fiction Studies 52.1 (2006): 187-97.

Pollock, Sheldon, et al. "Cosmopolitanisms." Cosmopolitanism. Ed. Sheldon Pollock et al. Durham: Duke UP, 2002. 1-14.

Pound, Ezra. "Hugh Selwyn Mauberly: Life and Contacts." The Norton Anthology of Modern Poetry. Ed. Richard Ellman and Robert O'Clair. New York: Norton, 1988. 382-89. 
Nels C. Pearson

Rajan, Gita, and Shailja Sharma. "New Cosmopolitanisms: South Asians in the United States at the Turn of the Twenty-First Century." New Cosmopolitanisms: South Asians in the US. Ed. Gita Rajan and Shailja Sharma. Stanford: Stanford UP, 2006. 1-36.

Robbins, Bruce. “Actually Existing Cosmopolitanism.” Cheah and Robbins $1-19$.

Said, Edward. Culture and Imperialism. New York:Vintage: 1994.

_ . "Reflections on Exile." Reflections on Exile. Cambridge: Harvard UP, 2000. 173-86.

Walkowitz, Rebecca. Cosmopolitan Style: Modernism beyond the Nation. New York: Columbia UP, 2006.

Wightman, Beth. "Geopolitics and the Sight of the Nation: Elizabeth Bowen's The Last September." Literature, Interpretation, Theory 18 (2007): 37-64.

Williams, Julia McElhattan. "Fiction with the Texture of History: Elizabeth Bowen's The Last September." Modern Fiction Studies 41 (1995): 219-42.

Woolf,Virginia. To The Lighthouse. New York: Harcourt, 1989.

- The Waves. New York: Harcourt, 1931. 